\title{
Should Trade Remedies be Eliminated from WTO: A Response to Tania Voon
}

\author{
Utkarsh K. Mishra a ${ }^{*}$, Abhishek Negia \\ a.bDharmashastra National Law University, Jabalpur, India \\ Corresponding author: utkarsh@mpdnlu.ac.in
}

\section{ARTICLE INFO}

Article history

Received: August 30, 2021

Revised: September 25, 2021

Accepted: October 15, 2021

\section{Keywords}

Regional Trade Agreements;

Safeguards;

Trade Remedies

\section{ABSTRACT}

This work is a reflection of a critical viewpoint on the academic work of Tania Voon. She argues on the elimination of trade remedies from the multilateral trading system of the World Trade Organization on the basis of various considerations, including on the basis of some lessons from Regional Trade Agreements. The article makes no attempt to strike a balance between consumer and domestic industry interests. Additionally, it must be recognized that eliminating a structural protection mechanism is not always the best course of action because, in a global market such as that of trade, there are numerous players with disparate interests. If trade remedies are eliminated, a void will exist in which there will be nothing to regulate short-term issues, which will also affect the WTO's long-term objectives.

This is an open-access article under the CC-BY 4.0 license.

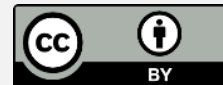

\section{Introduction}

Tania Voon is a Professor at Melbourne Law School, The University of Melbourne. She is a former Legal Officer of the Appellate Body Secretariat of the World Trade Organization (WTO) and has previously practiced law with Mallesons Stephen Jaques and the Australian Government Solicitor. Her article ${ }^{1}$ basically has a proposition to eliminate the three trade remedies from the WTO on the basis of two folds arguments. One is the economic irrationality and lesswelfare features of the trade remedies, and the other is that many regional trade agreements have modified, reduced, and eliminated the use of trade remedies such as anti-dumping measures, which has helped Regional Trade Agreements (RTAs) to enhance free and easy trade amongst their member states.

\footnotetext{
1Tania Voon, 'Eliminating Trade Remedies from the WTO: Lessons from Regional Trade Agreements', International $\mathcal{E}$ Comparative Law Quarterly, $59.3 \quad$ (2010), 625-67. https://doi.org/10.1017/S0020589310000254
} 
The article outlines the problems and loopholes in the present Trade Remedies' regime under WTO and proposes that trade remedies be eliminated for better welfare. Moreover, the article's concern is that whenever countries face problems with economic circumstances, there is always pressure to protect domestic industries, which results in enhanced and deadly protectionism that is opposed to the goals of WTO. The key highlights of the article, which are debatable, have been bulleted as the study strongly propagates that RTAs are multilateralizing regionalism, as Patrick Low and Richard Baldwin pointed out.

It takes the view of many economists that Trade Remedies are almost invariably inefficient. They are harmful not only for the exporters but also for importers. Anti-dumping and Countervailing measures ultimately create a higher-priced product for the consumers in the wake of protecting the domestic industries and hence are economically irrational. Nevertheless, the author takes a soft opinion about the Safeguard measures and believes that Safeguards act as safety valves for domestic industries facing a sudden increase in imports from other countries. Moreover, there is a general compensation scheme under the Safeguards regime of WTO to other affected members as it is imposed on an MFN basis as opposed to Anti-dumping and Counter-veiling measures. This also makes safeguards nondiscriminatory as opposed to the other two remedies. However, the study concern is that the safeguards regime under the WTO is almost redundant as it is used by the countries far less frequently than other remedies. ${ }^{2}$

The study suggests simply removing Trade remedies from the WTO regime and opines that competition disciplines in the place of these remedies would better serve the needs. However, it also points out that harmonizing a competition law regime for all WTO members is a long way off. The study supports its arguments through the model of most regional trade agreements that have either modified or removed trade remedies from their regulatory regime. The study sees such a scheme associated with deep integration characterized by harmonized measures that allow freer trade. The study admits that most developing and least developing countries depend on trade remedies for sustenance in the world trade market. The study puts consumer interest (concerning the price of the imported products) at a higher pedestal than the protection of domestic industry. Lastly, the study supports the idea of 'Bilateral safeguards or regional safeguards' measures adopted by some RTAs whereby they involve a reversion to MFN tariff

${ }^{2} \mathrm{~J}$ Michael Finger, Francis Ng, and Sonam Wangchuk, Antidumping as Safeguard Policy (The World Bank, 2001). Google Scholar; Herbert G Grubel and Peter J Lloyd, 'The Empirical Measurement of Intra-Industry Trade', Economic Record, 47.4 (1971), 494-517. Google Scholar; Reid W Click and Michael G Plummer, 'Stock Market Integration in ASEAN after the Asian Financial Crisis', Journal of Asian Economics, 16.1 (2005), 5-28. https://doi.org/10.1016/j.asieco.2004.11.018; Peter A Petri and Michael G Plummer, The Economic Effects of the Trans-Pacific Partnership: New Estimates, Peterson Institute for International Economics Working Paper, 2016. http://dx.doi.org/10.2139/ssrn.2723413 
rates only in particular circumstances, and sometimes they are allowed only for transitional periods for specific products/purposes.

\section{Results and Discussion}

\subsection{Trade Remedies be Eliminated from WTO}

The study to eliminate trade remedies from the WTO regime (without giving any alternative model for substitution) as proposed by Voon in 2010 is exceptionally new and revolutionary. There is abundant literature which talks about the success of RTAs as a model with modified/eliminated trade remedies regime as opposed to that under WTO. ${ }^{3}$ Nevertheless, there is little support for eliminating trade remedies from WTO just because RTAs are a success. A recent report by the Swedish government agency in 2013 by its Trade policy advisers ${ }^{4}$ emphasizes that $75 \%$ of the present RTAs include provisions on Competition discipline and looking at the operation and regulatory outcome of such harmonized competition structures like that in the European Union, it may be possible to replace anti-dumping measures with competition law disciplines which would provide a uniform model for regulating competition while at the same time ensuring freer trade prospects within the integrated arrangement. However, while elaborating on the proposition through the example of the EU, the report also mentions that even though it has employed competition disciplines to regulate its competition instead of using Anti-di-dumping measures, it still maintains the right to use anti-dumping measures against the third countries in particular situations. So, in essence, the EU has not entirely done away with the Anti-dumping measures to a certain extent.

There is another scholarly work by Zheng ${ }^{5}$ on trade remedies wherein the author agrees that trade remedies like anti-dumping are economically irrational. However, he does not propose eliminating such remedies from the purview of WTO governance completely and instead projects an alternative model as he

\footnotetext{
${ }^{3}$ Wentong Zheng, 'Reforming Trade Remedies', Mich. J. Int'l L., 34 (2012), 151. Google Scholar; Chad P Bown, 'Trade Remedies and World Trade Organization Dispute Settlement: Why Are so Few Challenged?', The Journal of Legal Studies, 34.2 (2005), 515-55. Google Scholar; Patrick A Messerlin, 'Anti-Dumping and Trade Remedies: A Necessary Reform', in The World Trade Organization Millennium Round (Routledge, 2001), pp. 160-72. Google Scholar; Febry Wulandari and Waluyo Waluyo, 'Efektivitas Pemanfaatan Dana Bagi Hasil Cukai Hasil Tembakau Dalam Bidang Kesehatan Di Kota Surakarta Tahun 2018', Bestuur, 7.2 (2020), 15. https://doi.org/10.20961/bestuur.v7i1.28418; Chad P Bown, The Global Resort to Antidumping, Safeguards, and Other Trade Remedies amidst the Economic Crisis, Effective Crisis Response and Openness: Implications for the Trading System, London, UK: CEPR and World Bank, 2009. Google Scholar

${ }^{4}$ Christina Romlid, 'Promoting Sweden: The Socioeconomic Section of the Swedish Pavilion Display at the 1937 World Fair in Paris', in World Fairs and the Global Moulding of National Identities (Brill, 2021), pp. 329-55 https://doi.org/10.1163/9789004500327_014; Liana Endah Susanti, 'Economic Law Creation Beautiful Global Indonesia', Bestuur, 7.2 (2020), 47. https://doi.org/10.20961/bestuur.v7i1.42701

${ }^{5}$ Zheng. Google Scholar
} 
believes that directly eliminating the trade remedies is not a viable solution. Replacing the same with a reform-based model that would also cater to functions that remedies like anti-dumping perform is desirable. He proposes the "Country Specific Safeguard model, " which has seven highlight markers of reforms. These are described in diagram 1.1.6

Diagram 1.1: Unfair Pricing Component

\section{Eliminating the unfair pricing component}

\section{A higher Injury standard as opposed to material injurt standard}

No

compensation Only tariffs on as in the global safeguard regime imports and no

import quoatas
A Mandatory

public interest clause
Imposition on country to country basis

Fixed duration of application but no limitation on frequency of usage

As seen from the diagram made above, the new country-specific model proposed by the said author, although replacing the Anti-dumping model as under WTO, also retains some of the features of the later model. He proposes not eliminating the trade remedies model without replacing it with another reform model. There is no popular support for completing doing away with the trade remedies regime. Even some regional trade agreements have modified the regime as under WTO to suit their needs but have not resorted to complete elimination.

\subsection{Critical Overview of Voon's Proposition}

While projecting the cause for the removal of trade remedies from the WTO regime, the article creates a lot of logical and consequential debates that need dire academic attention. It must be understood that most of the RTAs are a success because they adopted a modified version of trade remedies under the WTO, or removal of trade remedies from their regulatory structure does not logically conclude and support that all the trade remedies be removed from WTO as a whole. It must be understood that RTAs are special arrangements allowed under

\footnotetext{
${ }^{6}$ The diagram is based on the 'Country specific model' as proposed by Wentong Zheng in 2012. Google Scholar
} 
exceptional circumstances under the GATT, 1994. So the fashion in which these RTAs work is very different from the general obligations as stated WTO rules. ${ }^{7}$

Secondly, the proposal to eliminate trade remedies by citing the examples of RTAs as role models would instill in countries a tendency to enter more and more into regional trade agreements, hence diluting the mandate of WTO, which is multilateral trade rather than regional trade. According to many economists like Jagdish Bhagwati, ever-increasing RTAs will create stumbling blocks to the spirit of multilateral trade as RTAs allow countries to have their regulatory structures to a certain extent, which in turn would give vent to a trade block mentality. Moreover, in the words of another economist, namely Jacob Viner, it may lead to trade diversion instead of trade creation.

Thirdly, the article has differentiated immensely between the level of importance to be given to domestic industries and the consumers' interests. It is good to look towards the welfare of the consumers, but then, even domestic industries cannot be put in jeopardy by eliminating trade remedies. Fourthly, Prof Tania Voon argues only on removing trade remedies from WTO and does not propose any other alternative model. Taking the example of the European Union, even though it has put in place competition disciplines to regulate matters that the trade remedies regime would otherwise regulate, it has still kept the option of using trade remedies like Anti-dumping duties open in case of third countries in particular given situations. Similarly, the model proposed by Zheng is reformative, which is desirable as opposed to the one proposed by Voon, which is entirely one-sided and incomplete in itself.

Fifth, the article admits that most developing and least developing countries depend on trade remedies regime under the WTO for sustenance in world trade, but still, it proposes removing them from the WTO regulatory structure. This implies a weaker sensitivity towards the interests of developing countries and hence is a biased proposal. Sixth, the article is underlining basis is the global economic crisis problem due to which countries are bound to protect their domestic countries, ${ }^{8}$ which results in enhanced protectionism. It must be understood that economic crisis is not a permanent phenomenon. It comes and goes and does not stay forever. It is an exceptional circumstance when even the WTO permits the countries to protect their domestic industries. Hence the foundation of the article itself seems to be based on a flawed and incomplete

7Peter Hilpold, 'Regional Integration According to Article XXIV GATT-between Law and Politics', Max Planck Yearbook of United Nations Law Online, 7.1 (2003), 219-60 https://doi.org/10.1163/187574103X00040; See also Zakir Hafez, ‘Weak Discipline: GATT Article XXIV and the Emerging WTO Jurisprudence on RTAs', NDL Rev., 79.4 (2003), 879. Google Scholar

${ }^{8}$ Erica Marat, Labor Migration in Central Asia: Implications of the Global Economic Crisis (Washington DC: Silk Road Studies Program, Institute for Security and Development Policy ..., 2009). Google Scholar; Nur Putri Hidayah, Quincy R Cloet, and David Pradhan, 'The Implementation of Labor Development Principles According to Job Creation Law as a Reason to Protect Wages Rights', BESTUUR, 9.1 (2021), 94-105 https://doi.org/10.20961/bestuur.v9i1.49252 
understanding of the issue. If at all, the present anti-dumping or counter-veiling code is causing problems for countries. ${ }^{9}$ The solution is not to simply do away with them but to reform the whole structure, like many developing and least developing countries are dependent on trade remedies for economic survival.

\section{Conclusion}

As the analysis above showcases, the foundation and understanding on which Voon's article is based are skewed and devoid of a holistic analysis of the problem. Most importantly, the article ignores the interests of developing and least developing countries, which is at the core of WTO negotiations these days. Another more prominent flaw that the article does is not to adopt a balancing approach between the interests of consumers and domestic industries. It must also be understood that removing a structural protection mechanism is not always a solution because, in a world market like that of trade, there are various players with a myriad of interests. If the trade remedies are eliminated, a void would be wherein there would be nothing to regulate the short-term problems, which would also affect the long-term goals of the WTO. Hence, the reformative approach is always suggested, which gives an alternative and provides a better understanding of the problems the current structural mechanism is going through.

\section{References}

Alam, Muhammad M, Does WTO Dispute Settlement Provide Effective Remedies for Anti-Dumping Measure?, 2007. Google Scholar

Bown, Chad P, The Global Resort to Antidumping, Safeguards, and Other Trade Remedies amidst the Economic Crisis, Effective Crisis Response and Openness: Implications for the Trading System, London, UK: CEPR and World Bank, 2009. Google Scholar

- - - 'Trade Remedies and World Trade Organization Dispute Settlement: Why Are so Few Challenged?', The Journal of Legal Studies, 34.2 (2005), 515-55. Google Scholar

Click, Reid W, and Michael G Plummer, 'Stock Market Integration in ASEAN after the Asian Financial Crisis', Journal of Asian Economics, 16.1 (2005), 5-28 https://doi.org/10.1016/j.asieco.2004.11.018

Finger, J Michael, Francis Ng, and Sonam Wangchuk, Antidumping as Safeguard Policy (The World Bank, 2001). Google Scholar

Grubel, Herbert G, and Peter J Lloyd, 'The Empirical Measurement of Intra-Industry Trade', Economic Record, 47.4 (1971), 494-517. Google Scholar Hafez, Zakir, 'Weak Discipline: GATT Article XXIV and the Emerging WTO Jurisprudence on RTAs', NDL Rev., 79.4 (2003), 879. Google Scholar

\footnotetext{
${ }^{9}$ Muhammad M Alam, Does WTO Dispute Settlement Provide Effective Remedies for Anti-Dumping Measure?, 2007. Google Scholar
} 
Hidayah, Nur Putri, Quincy R Cloet, and David Pradhan, 'The Implementation of Labor Development Principles According to Job Creation Law as a Reason to Protect Wages Rights', BESTUUR, $9.1 \quad$ (2021), 94-105 https://doi.org/10.20961/bestuur.v9i1.49252

Hilpold, Peter, 'Regional Integration According to Article XXIV GATT - between Law and Politics', Max Planck Yearbook of United Nations Law Online, 7.1 (2003), 219-60 https://doi.org/10.1163/187574103X00040

Marat, Erica, Labor Migration in Central Asia: Implications of the Global Economic Crisis (Washington DC: Silk Road Studies Program, Institute for Security and Development Policy ..., 2009). Google Scholar

Messerlin, Patrick A, 'Anti-Dumping and Trade Remedies: A Necessary Reform', in The World Trade Organization Millennium Round (Routledge, 2001), pp. 16072 .

Google Scholar

Petri, Peter A, and Michael G Plummer, The Economic Effects of the Trans-Pacific Partnership: New Estimates, Peterson Institute for International Economics Working Paper, 2016. https://doi.org/10.2139/ssrn.2723413

Romlid, Christina, 'Promoting Sweden: The Socioeconomic Section of the Swedish Pavilion Display at the 1937 World Fair in Paris', in World Fairs and the Global Moulding of National Identities (Brill, 2021), pp. 329-55. https://doi.org/10.1163/9789004500327_014

Susanti, Liana Endah, 'Economic Law Creation Beautiful Global Indonesia', Bestuur, 7.2 (2020), 47. https://doi.org/10.20961/bestuur.v7i1.42701

Voon, Tania, 'Eliminating Trade Remedies from the WTO: Lessons from Regional Trade Agreements', International \& Comparative Law Quarterly, 59.3 (2010), 625-67. https://doi.org/10.1017/S0020589310000254

Wulandari, Febry, and Waluyo Waluyo, 'Efektivitas Pemanfaatan Dana Bagi Hasil Cukai Hasil Tembakau Dalam Bidang Kesehatan Di Kota Surakarta Tahun 2018', Bestuur, 7.2 (2020), 15. https://doi.org/10.20961/bestuur.v7i1.28418

Zheng, Wentong, 'Reforming Trade Remedies', Mich. J. Int'l L., 34 (2012), 151. Google Scholar 